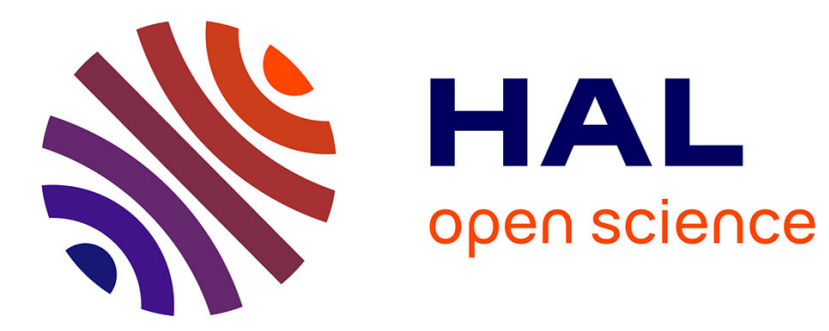

\title{
Invasive aspergillosis due to Aspergillus cryptic species: A prospective multicentre study
}

Sebastien Imbert, Sophie Cassaing, Christine Bonnal, Anne-cecile Normand, Frederic Gabriel, Damien Costa, Marion Blaize, Laurence Lachaud, Lilia Hasseine, Lise Kristensen, et al.

\section{To cite this version:}

Sebastien Imbert, Sophie Cassaing, Christine Bonnal, Anne-cecile Normand, Frederic Gabriel, et al.. Invasive aspergillosis due to Aspergillus cryptic species: A prospective multicentre study. Mycoses, 2021, 10.1111/myc.13348. hal-03390620

\section{HAL Id: hal-03390620 \\ https: / hal.sorbonne-universite.fr/hal-03390620}

Submitted on 21 Oct 2021

HAL is a multi-disciplinary open access archive for the deposit and dissemination of scientific research documents, whether they are published or not. The documents may come from teaching and research institutions in France or abroad, or from public or private research centers.
L'archive ouverte pluridisciplinaire HAL, est destinée au dépôt et à la diffusion de documents scientifiques de niveau recherche, publiés ou non, émanant des établissements d'enseignement et de recherche français ou étrangers, des laboratoires publics ou privés. 
DR SEBASTIEN IMBERT (Orcid ID : 0000-0003-4187-0806)

DR LAURENCE LACHAUD (Orcid ID : 0000-0001-6761-8161)

Article type : Original Article

Invasive aspergillosis due to Aspergillus cryptic species: a prospective multicenter study

Running title: Invasive aspergillosis due to cryptic species

Sebastien Imbert ${ }^{1,2 \#}$, Sophie Cassaing ${ }^{3}$, Christine Bonnal ${ }^{4}$, Anne-Cecile Normand ${ }^{1}$, Frederic Gabriel$^{5}$, Damien Costa ${ }^{6}$, Marion Blaize ${ }^{1,2}$, Laurence Lachaud ${ }^{7}$, Lilia Hasseine ${ }^{8}$, Lise Kristensen', Juliette Guitard ${ }^{10}$, Christine Schuttler ${ }^{11}$, Helene Raberin ${ }^{12}$, Sophie Brun ${ }^{13}$, Marijke Hendrickx ${ }^{14}$, Renaud Piarroux ${ }^{1,15}$, Arnaud Fekkar ${ }^{1,2}$

${ }^{1}$ AP-HP, Groupe Hospitalier La Pitié-Salpêtrière, Service de Parasitologie Mycologie, F-75013, Paris, France

${ }^{2}$ Sorbonne Université, Inserm, CNRS, Centre d'Immunologie et des Maladies Infectieuses, Cimi-Paris, F-75013, Paris, France

${ }^{3}$ Centre Hospitalier Universitaire de Toulouse, Service de Parasitologie Mycologie, F-31059, Toulouse, France

${ }^{4}$ AP-HP, Hôpital Bichat-Claude Bernard, Service de Parasitologie Mycologie, F-75018 Paris, France

${ }_{5}^{5}$ Centre Hospitalier Universitaire de Bordeaux, Service de Parasitologie Mycologie, F-33000, Bordeaux, France

${ }^{6}$ Centre Hospitalier Universitaire de Rouen, Service de Parasitologie Mycologie, F-76000, Rouen, France

${ }^{7}$ Centre Hospitalier Universitaire de Montpellier, Service de Parasitologie Mycologie, F-34000, Montpellier, France

${ }^{8}$ Centre Hospitalier Universitaire de Nice, Service de Parasitologie Mycologie, F-06000, Nice, France

${ }^{9}$ Aarhus University Hospital, Department of Clinical Microbiology, DK-8200, Aarhus N, Denmark

${ }^{10}$ AP-HP, Hôpital Saint-Antoine, Service de Parasitologie Mycologie, F-75012, Paris, France

${ }^{11}$ Laboratoire Biogroup-LCD, F-92300, Levallois, France

12 Centre Hospitalier Universitaire de Saint Etienne, Service de Parasitologie Mycologie, F-42100, Saint Etienne, France

13 AP-HP, Hôpital Avicenne, Service de Parasitologie Mycologie, F-93000 Bobigny, France

${ }^{14}$ Service of Mycology and Aerobiology, BCCM/IHEM Fungal collection, Scientific Institute of Public Health, B1050, Brussels, Belgium

This article has been accepted for publication and undergone full peer review but has not been through the copyediting, typesetting, pagination and proofreading process, which may lead to differences between this version and the Version of Record. Please cite this article as doi: $\underline{10.1111 / M Y C .13348}$

This article is protected by copyright. All rights reserved 
${ }^{15}$ Sorbonne Université, Inserm, Institut Pierre Louis d'Epidemiologie et de Santé Publique, F-75013, Paris, France

\#Corresponding author: S. Imbert

E-mail: sebastien.imbert@u-bordeaux.fr

Tel: +33 557820982 Fax: +33 59795673

Current address: Service de parasitologie-mycologie, Hôpital Pellegrin, place Amelie Raba Leon, 33075 Bordeaux CEDEX

\section{TRANSPARENCY DECLARATION}

This study was supported by internal funding.

Keywords: Invasive aspergillosis, cryptic species, antifungal resistance, Aspergillus sublatus, Aspergillus calidoustus, EUCAST, molecular epidemiology, azole prophylaxis

\section{ABSTRACT (243 words)}

Objectives: Aspergillus cryptic species are increasingly recognized causes of Aspergillus diseases, including life-threatening invasive aspergillosis (IA). However, as their accurate identification remains challenging in a routine practice, few is known from a clinical and epidemiological perspective. Recently, the MSI application has emerged as a powerful tool for the detection and identification of Aspergillus cryptic species. We aimed to use to the network of users of the MSI application to conduct a multicenter prospective screening of Aspergillus cryptic species related IA and analyze their epidemiological, clinical and mycological characteristics.

Methods: Over a 27-month period, the clinical involvement of 369 Aspergillus cryptic isolates, from 13 French and Danish MSI application users, was prospectively analyzed. Species identification was confirmed by DNA-sequencing and antifungal susceptibility testing was performed using EUCAST reference method. Fifty-one A. fumigatus sensu stricto invasive cases were also analyzed.

Results: Fifteen cryptic isolates were responsible of IA. Eight species were involved, including 5 cases related to the species A. sublatus. These species showed high rate of in vitro low susceptibility to antifungal drugs. In comparison with A. fumigatus sensu stricto invasive cases, pre-exposure to azole drugs was significantly associated with cryptic IA $(p=0.02)$.

Discussion: This study brings new insights in cryptic species related IA and underlines the importance to identify accurately at the species level these Aspergillus isolates. The increasing use 
of antifungal drugs might lead in the future to an epidemiologic shift with an emergence of resistant isolates involved in IA.

\section{INTRODUCTION (1763 words)}

Aspergillus spp. are the most frequent filamentous fungi involved in human pathology. They are responsible for a wide spectrum of diseases, including invasive aspergillosis (IA), a lifethreatening disease with an overall 3-month mortality up to 50\%. ${ }^{1,2}$ Historically, few Aspergillus species were involved in human aspergillosis, the most frequent species being A. fumigatus, then A. niger, A. flavus, A. nidulans and A. terreus. ${ }^{3-6}$ However, in recent years, Aspergillus species taxonomy has been changed in depth by the introduction of the new concept of cryptic species. This latter encompasses species non-distinguishable by morphological characteristics which are gathered into a single species complex called "section". The most recent taxonomy update reports 436 Aspergillus species distributed into 27 sections. $^{7}$ The presence of Aspergillus cryptic species in clinical samples is increasingly reported, changing so aspergillosis epidemiology. ${ }^{8}$ Currently, more than 100 species have been reported in clinical samples, including 30 species responsible for IA. ${ }^{9}$ Data are scarce but retrospective multicenter studies have shown that Aspergillus cryptic species were involved between $10 \%$ to $30 \%$ of invasive cases. ${ }^{10-12}$

Beyond the taxonomic interest, the notion of cryptic species is of great interest given the link between a given species and its susceptibility to antifungal drugs as it has been shown for several sections. ${ }^{13,14}$ Unlike aspergillosis due to A. fumigatus sensu stricto, cryptic species related infections are less detailed from a clinical and epidemiological perspective. Lack of data may be related to difficulties in routinely obtaining accurate identification. Indeed, identification based on morphology, which is the easiest to implement and the most commonly shared in microbiology laboratories, is inadequate to distinguish different cryptic species within a section. Sequence-based identification, which represents the gold standard method, ${ }^{7}$ cannot be universally applied in routine settings. Finally, identification by matrix-assisted laser desorption ionization time-of-flight (MALDI-TOF) mass spectrometry, although suitable for identification of Aspergillus spp., directly relies on the quality and completeness of the database used. ${ }^{15}$ Commercial databases dedicated to fungi often fail to provide relevant mold identification as they usually include very few cryptic species. ${ }^{15}$ The mass spectrometry identification (MSI) application is an independent and freely accessible online database (https://msi.happy-dev.fr), dedicated to the identification of various parasitic and fungal pathogenic agents, from their mass spectra acquired by Bruker ${ }^{\circledR}$ MALDI-TOF Microflex ${ }^{16,17}$. The fungal database was built in collaboration with the BCCM/IHEM (Belgian 
Coordinated Collections of Micro-organisms/Institute of Hygiene and Epidemiology Mycology) and is, to our knowledge, the most extensive for filamentous fungi. Recently we demonstrated that this MSI application was a powerful tool for the detection and identification of Aspergillus cryptic species. $^{18}$

The aim of this study was to take advantage of the network of users of the MSI application for prospective screening of cryptic species related IA and to analyze their epidemiological, clinical and mycological characteristics.

\section{METHODS}

Over a 27-month period (August 2017 - October 2019), a standardized clinical report form was prospectively fulfilled by 13 French and Danish MSI application users each time they identified an Aspergillus cryptic species. Isolates and forms were sent anonymously to the La Pitié-Salpêtrière Hospital, Paris, France for data management, according to French legislation on human research. If applicable, cases were classified as proven or probable IA according to the criteria of the European Organization of Research and Treatment of Cancer (EORTC) / Mycoses Study Group Education and Research Consortium (MSGERC), ${ }^{19}$ or putative IA according to the AspICU criteria for intensive care unit patients. ${ }^{20}$ These latter encompass a positive culture of the respiratory tract with a positive direct examination, associated with clinical and imaging criteria, in the absence of EORTC/MSGERG risk factors.

Species identification was confirmed by sequencing a part of the beta-tubulin and calmodulin genes. Primer pairs Bt2a/Bt2b for beta-tubulin and CL1/CL2A or cmd5/cmd6 for calmodulin, were used as previously described. ${ }^{21}$ The resulting DNA sequences were analyzed using ChromasPro v1.7.1 (Technelysium Pty Ltd) and most were deposited on Genbank (accession numbers MK297710 - MK297892 and MK297532 - MK297699). All isolates responsible of IA were assessed for antifungal susceptibility testing (AFST) by broth microdilution (BMD) reference method, according to EUCAST guidelines, vE.DEF 9.3.1 (https://www.eucast.org/fileadmin/src/media/PDFs/EUCAST_files/AFST/Files/EUCAST_E_Def_ 9.3.1_Mould_testing_definitive_revised_2020.pdf). Five antifungal drugs were assessed with final drug concentration ranges of 0.016 to $8 \mathrm{mg} / \mathrm{L}$ for posaconazole and itraconazole and 0.03 to 16 $\mathrm{mg} / \mathrm{L}$ for voriconazole, isavuconazole and amphotericin B. One among three quality control strains (C. parapsilosis ATCC 22019, C. krusei ATCC 6258 and A. fumigatus ATCC 204305) was 
included in each plate alternatively. All isolates recovered over the study period and belonging to cryptic species involved in IA, were also assessed for AFST.

We also sought to compare cryptic IA data with those of $A$. fumigatus sensu stricto related IA. For this purpose, we analyzed all IA cases for which an A. fumigatus sensu stricto culture had been obtained from 2 centers, resulting in a total of 51 "control" cases over the same study period.

\section{RESULTS}

Clinical involvement was recovered for 369 cryptic isolates belonging to 67 species from 13 sections. The Nidulantes section was the most represented (119 isolates, 16 species) followed by the section Nigri (53 isolates, 7 species), Fumigati (49 isolates, 7 species) and Circumdati (48 isolates, 8 isolates).

Fifteen isolates (4.1\%), from four centers, were responsible of IA ( 2 proven, 11 probable and 2 putative). The Nidulantes section was the most frequent (6 cases), followed by the sections Usti and Fumigati (three cases each). The remaining isolates belonged to the Nigri $(\mathrm{n}=2)$ and the Flavi $(\mathrm{n}=1)$ sections (Table 1). Beside these invasive isolates, 17 were involved in chronic pulmonary aspergillosis, 225 in bronchial colonization, 53 in superficial infection (onychomycosis and otomycosis) and 59 were considered as non-clinically relevant.

As shown in Table 1, the main underlying condition for cryptic IA was solid organ transplantation $(n=6,40 \%)$, then hematological malignancy $(n=5,33.3 \%)$ and acute respiratory distress syndrome in intensive care unit's patients $(n=3,20 \%)$. This latter included two patients with severe influenza infection requiring extra-corporeal membrane oxygenation. A majority of patients $(n=13,86.7 \%)$ were receiving immunosuppressive therapy, including 10 (66.7\%) with corticosteroids. Five patients were neutropenic (neutrophil count $<500 / \mathrm{mm}^{3}$ ) at time of IA diagnosis. An ongoing antimould active treatment initiated before the diagnosis of IA was reported in five patients (four with an azole drug and one with an echinocandin). Interestingly, two A. calidoustus cases occurred in patients previously treated by voriconazole against a probable A. fumigatus IA. All patients received a targeted antifungal therapy, including $6(40 \%)$ with multiple antifungal drugs. Thirteen patients $(86,7 \%)$ received at least one line of azole-based therapy. Overall three-month mortality was $60 \%(9 / 15)$, including four of the five patients infected by $A$. sublatus. 
All IA isolates, except the 5 A. latus isolates, exhibited high Minimal Inhibitory Concentrations (MICs) to at least one drug. A. alliaceus and A. tubingensis showed very high MICs to a unique drug (amphotericin B and itraconazole respectively) (Table 2). A. calidoustus showed pan-azole high MICs. Species from the Fumigati section and A. sydowii showed multidrug resistance with high MICs to azole drugs and amphotericin B, and high MICs to itraconazole, posaconazole and amphotericin B respectively. These species-specific antifungal susceptibility patterns, were confirmed on a greater number of isolates, with ranges, MIC50 and MIC90 in accordance to IA isolates MICs (Table 2).

As shown in Table 3, no significant differences in patient characteristics, clinical presentation or 3-month outcome were observed between cryptic IA and the 51 A. fumigatus sensu stricto relatedIA. The only parameter which was associated with the occurrence of cryptic IA was an ongoing azole drug treatment at the time of IA diagnosis $(\mathrm{p}=0.02)$.

\section{DISCUSSION}

Invasive aspergillosis due to cryptic species remains rare disease. In this multicentric prospective study, the MSI application user network allowed us to collect clinical and microbiological data for 369 cryptic Aspergillus isolates, from 13 centers in France and Denmark. To note, over the study period (27 months), 4602 Aspergillus cryptic isolates were identified on the application, over the 15305 Aspergillus total isolates (30.1\%), by 112 centers in 19 countries.

Among the 369 cryptic isolates included in the study, only 15 were linked to invasive diseases They belong to eight distinct cryptic species distributed into five sections. The species $A$. sublatus was the most abundant (five cases) of this case series, although few cases are reported in literature. ${ }^{22}$ However, A. sublatus could be more frequent as previously expected inside the Nidulantes section. Data from the MSI application routine utilization reinforce this observation, since $A$. sublatus accounts for as many identifications as $A$. nidulans (data not shown). The same phenomenon has already been described for the species A. tubingensis and A. calidoustus in the Nigri and Usti sections respectively. ${ }^{23,24}$ Consequently, the classification of species into cryptic or non-cryptic is likely to evolve over time, depending on subsequent epidemiological studies. In contrast, cryptic species from the sections Fumigati and Flavi remain less frequent than the sensu stricto species A. fumigatus and A. flavus respectively. In this study we report a species diversity inside the section Fumigati, with three distinct species involved in IA. This is consistent with 
previous reports where not less than 10 cryptic species from the Fumigati section have been described in IA.

One of the pitfalls to a better understanding of cryptic species related IA is that only cases with a positive culture can be considered, which, given the modest sensitivity of the culture for diagnosis, limits the number of cases considered. For the two centers with exhaustive data, cryptic IA account for $21 \%$ and $18.8 \%$ of the total number of IA with a positive culture, which is consistent with previous reports. ${ }^{11,12}$

Most importantly, pre-exposure to azole drugs was significantly associated with occurrence of IA due to cryptic species in comparison to those related to A. fumigatus sensu stricto. This might be explained by the high rate of azole decreased susceptibility observed in cryptic species. Indeed, while the sensu stricto species A. fumigatus is naturally pan-susceptible to antifungal drugs, Fumigati cryptic species exhibit decreased susceptibility to azole drugs and/or amphotericin B, which is consistent with previous results. ${ }^{13,14}$ Pan-azole resistance is the rule for $A$. calidoustus isolates, as previously reported for the whole Usti section. ${ }^{24}$ Finally, A. sydowii exhibits high MICs to azole drugs and amphotericin B. However, despite this decreased susceptibility, no other significant differences with A. fumigatus cases were observed, including 3-month outcome. Nevertheless, the increasing use of antifungal drugs might lead in the future to an epidemiologic shift with an emergence of resistant isolates in clinical practice, as already suggested with the use of azole prophylaxis. ${ }^{25}$

In conclusion, this study brings new insights in cryptic species related IA and underlines the importance to identify accurately at the species level these Aspergillus isolates, given their intrinsic low susceptibility to antifungal drugs.

\section{AUTHOR'S CONTRIBUTIONS}

SI designed the study, performed experiments, centralized data and wrote the manuscript, $\mathrm{SC}, \mathrm{CB}$, FG, DC, MB, LL, LH, LK, JG, CS, HR, SB and MH participated in data collection, ACN performed experiments, RP participated in the design of the study, AF designed the study and participated in the writing.

\section{REFERENCES}

1. Kosmidis C, Denning DW. The clinical spectrum of pulmonary aspergillosis. Thorax. 2015;70(3):270-277. doi:10.1136/thoraxjnl-2014-206291 
2. Lestrade PP, Bentvelsen RG, Schauwvlieghe AFAD, et al. Voriconazole Resistance and Mortality in Invasive Aspergillosis: A Multicenter Retrospective Cohort Study. Clinical Infectious Diseases. 2019;68(9):1463-1471. doi:10.1093/cid/ciy859

3. Steinbach WJ, Marr KA, Anaissie EJ, et al. Clinical epidemiology of 960 patients with invasive aspergillosis from the PATH Alliance registry. $J$ Infect. 2012;65(5):453-464. doi:10.1016/j.jinf.2012.08.003

4. Lortholary O, Gangneux J-P, Sitbon K, et al. Epidemiological trends in invasive aspergillosis in France: the SAIF network (2005-2007). Clinical Microbiology and Infection. 2011;17(12):1882-1889. doi:10.1111/j.1469-0691.2011.03548.x

5. Kontoyiannis DP, Marr KA, Park BJ, et al. Prospective Surveillance for Invasive Fungal Infections in Hematopoietic Stem Cell Transplant Recipients, 2001-2006: Overview of the Transplant-Associated Infection Surveillance Network (TRANSNET) Database. Clinical Infectious Diseases. 2010;50(8):1091-1100. doi:10.1086/651263

6. Neofytos D, Fishman JA, Horn D, et al. Epidemiology and outcome of invasive fungal infections in solid organ transplant recipients: Invasive fungal infections in SOT. Transplant Infectious Disease. 2010;12(3):220-229. doi:10.1111/j.1399-3062.2010.00492.x

7. Houbraken J, Kocsubé S, Visagie CM, et al. Classification of Aspergillus, Penicillium, Talaromyces and related genera (Eurotiales): An overview of families, genera, subgenera, sections, series and species. Studies in Mycology. 2020;95:5-169. doi:10.1016/j.simyco.2020.05.002

8. Gautier M, Normand A-C, Ranque S. Previously unknown species of Aspergillus. Clinical Microbiology and Infection. 2016;22(8):662-669. doi:10.1016/j.cmi.2016.05.013

9. Tsang C-C, Tang JYM, Lau SKP, Woo PCY. Taxonomy and evolution of Aspergillus, Penicillium and Talaromyces in the omics era - Past, present and future. Computational and Structural Biotechnology Journal. 2018;16:197-210. doi:10.1016/j.csbj.2018.05.003

10. Balajee SA, Kano R, Baddley JW, et al. Molecular Identification of Aspergillus Species Collected for the Transplant-Associated Infection Surveillance Network. Journal of Clinical Microbiology. 2009;47(10):3138-3141. doi:10.1128/JCM.01070-09

11. Alastruey-Izquierdo A, Alcazar-Fuoli L, Rivero-Menéndez O, et al. Molecular Identification and Susceptibility Testing of Molds Isolated in a Prospective Surveillance of Triazole Resistance in Spain (FILPOP2 Study). Antimicrob Agents Chemother. 2018;62(9):e00358-18, /aac/62/9/e00358-18.atom. doi:10.1128/AAC.00358-18

This article is protected by copyright. All rights reserved 
12. Cho S-Y, Lee D-G, Kim W-B, et al. Epidemiology and Antifungal Susceptibility Profile of Aspergillus Species: Comparison between Environmental and Clinical Isolates from Patients with Hematologic Malignancies. Journal of Clinical Microbiology. 2019;57(7):e02023-18, /jcm/57/7/JCM.02023-18.atom. doi:10.1128/JCM.02023-18

13. Alastruey-Izquierdo A, Alcazar-Fuoli L, Cuenca-Estrella M. Antifungal susceptibility profile of cryptic species of Aspergillus. Mycopathologia. 2014;178(5-6):427-433. doi:10.1007/s11046-014-9775-z

14. Imbert S, Normand AC, Cassaing S, et al. Multicentric Analysis of the Species Distribution and Antifungal Susceptibility of Cryptic Isolates from Aspergillus Section Fumigati. Antimicrob Agents Chemother. 2020;64(12):e01374-20, /aac/64/12/AAC.01374-20.atom. doi:10.1128/AAC.01374-20

15. Normand A-C, Cassagne C, Gautier M, et al. Decision criteria for MALDI-TOF MS-based identification of filamentous fungi using commercial and in-house reference databases. $B M C$ Microbiol. 2017;17(1):25. doi:10.1186/s12866-017-0937-2

16. Normand AC, Becker P, Gabriel F, et al. Validation of a New Web Application for Identification of Fungi by Use of Matrix-Assisted Laser Desorption Ionization-Time of Flight Mass Spectrometry. Journal of Clinical Microbiology 2017;55(9):2661-2670. doi:10.1128/JCM.00263-17

17. Lachaud L, Fernández-Arévalo A, Normand A-C, et al. Identification of Leishmania by Matrix-Assisted Laser Desorption Ionization-Time of Flight (MALDI-TOF) Mass Spectrometry Using a Free Web-Based Application and a Dedicated Mass-Spectral Library. Journal of Clinical Microbiology 2017;55(10):2924-2933. doi:10.1128/JCM.00845-17

18. Imbert S, Normand AC, Gabriel F, et al. Multi-centric evaluation of the online MSI platform for the identification of cryptic and rare species of Aspergillus by MALDI-TOF. Medical Mycology. 2019;57(8):962-968. doi:10.1093/mmy/myz004

19. Donnelly JP, Chen SC, Kauffman CA, et al. Revision and Update of the Consensus Definitions of Invasive Fungal Disease From the European Organization for Research and Treatment of Cancer and the Mycoses Study Group Education and Research Consortium. Clinical Infectious Diseases. Published online December 5, 2019:ciz1008. doi:10.1093/cid/ciz1008

20. Blot SI, Taccone FS, Van den Abeele A-M, et al. A Clinical Algorithm to Diagnose Invasive Pulmonary Aspergillosis in Critically Ill Patients. Am J Respir Crit Care Med. 2012;186(1):56-64. doi:10.1164/rccm.201111-1978OC

This article is protected by copyright. All rights reserved 
21. Samson RA, Visagie CM, Houbraken J, et al. Phylogeny, identification and nomenclature of the genus Aspergillus. Studies in Mycology. 2014;78:141-173. doi:10.1016/j.simyco.2014.07.004

22. Chrenkova V, Hubka V, Cetkovsky P, et al. Proven Invasive Pulmonary Aspergillosis in Stem Cell Transplant Recipient Due to Aspergillus sublatus, a Cryptic Species of A. nidulans. Mycopathologia. 2018;183(2):423-429. doi:10.1007/s11046-017-0223-8

23. Carrara B, Richards R, Imbert S, et al. Species Distribution and Comparison between EUCAST and Gradient Concentration Strips Methods for Antifungal Susceptibility Testing of 112 Aspergillus Section Nigri Isolates. Antimicrob Agents Chemother. Published online April 20, 2020:AAC.02510-19, aac;AAC.02510-19v1. doi:10.1128/AAC.02510-19

24. Glampedakis E, Cassaing S, Fekkar A, et al. Invasive aspergillosis due to Aspergillus section Usti: a multicenter retrospective study. Clinical Infectious Diseases. Published online March 10, 2020. doi:10.1093/cid/ciaa230

25. Lamoth F, Chung SJ, Damonti L, Alexander BD. Changing Epidemiology of Invasive Mold Infections in Patients Receiving Azole Prophylaxis. Clinical Infectious Diseases. 2017;64(11):1619-1621. doi:10.1093/cid/cix130 
Table 1: patient characteristics, clinical presentation and outcome for the 15 cases of invasive aspergillosis related to Aspergillus cryptic

\begin{tabular}{|c|c|c|c|c|c|c|c|c|c|c|c|c|c|c|}
\hline \multirow[b]{2}{*}{ Patients } & \multirow[b]{2}{*}{ Sex } & \multirow[b]{2}{*}{$\begin{array}{c}\text { Age } \\
\text { (years) }\end{array} \mid$} & \multirow[b]{2}{*}{$\begin{array}{l}\text { Underlying } \\
\text { diseases }\end{array}$} & \multirow[b]{2}{*}{$\begin{array}{c}\text { Neutropenia } \\
(<500 / \mu \mathrm{L})\end{array}$} & \multicolumn{9}{|c|}{ species } & \multirow[b]{2}{*}{$\begin{array}{l}\text { 3-month } \\
\text { outcome }\end{array}$} \\
\hline & & & & & $\begin{array}{c}\text { Immunosuppressive } \\
\text { therapy }\end{array}$ & $\begin{array}{c}\text { Antifungal } \\
\text { pre- } \\
\text { exposure } \\
\text { (dosage) }\end{array}$ & $\begin{array}{c}\text { Invasive } \\
\text { aspergillosis } \\
\text { classification }\end{array}$ & $\begin{array}{c}\text { Radiological } \\
\text { findings }\end{array}$ & Section & Species & $\begin{array}{r}\text { Galacte } \\
\text { in } \\
\text { BAL }\end{array}$ & $\begin{array}{l}\text { manann } \\
\text { Sex } \\
\text { Serum }\end{array}$ & $\begin{array}{c}\text { Targeted } \\
\text { antifungal } \\
\text { therapy } \\
\text { (dosage) }\end{array}$ & \\
\hline $\begin{array}{c}\text { Patient } \\
01\end{array}$ & $\mathrm{~F}$ & 50 & $\begin{array}{c}\text { Solid organ } \\
\text { transplant (lung) }\end{array}$ & No & $\begin{array}{c}\text { Corticosteroids }+ \\
\text { calcineurin inhibitor } \\
+ \text { mycophenolate }\end{array}$ & No & $\begin{array}{c}\text { Probable } \\
\text { (lung) }\end{array}$ & $\begin{array}{c}\text { Bilateral } \\
\text { ground glass } \\
\text { opacities }\end{array}$ & Usti & $\begin{array}{c}\text { A. } \\
\text { calidoustus }\end{array}$ & $\mathrm{NA}^{\#}$ & 0.52 & $\begin{array}{l}\text { Voriconazole } \\
\left(\mathrm{NA}^{\#}\right) \text { then } \\
\text { posaconazole } \\
\left(\mathrm{NA}^{\#}\right)+ \\
\text { aerosolized } \\
\text { amphotericin } \\
\text { B }\end{array}$ & Alive \\
\hline $\begin{array}{c}\text { Patient } \\
02\end{array}$ & $\mathrm{~F}$ & 44 & $\begin{array}{c}\text { Solid organ } \\
\text { transplant (lung) }\end{array}$ & No & $\begin{array}{c}\text { Corticosteroids }+ \\
\text { calcineurin inhibitor } \\
+ \text { mycophenolate }\end{array}$ & No & $\begin{array}{l}\text { Probable } \\
\text { (lung) }\end{array}$ & $\begin{array}{c}\text { Lung } \\
\text { consolidations }\end{array}$ & Fumigati & A. fischeri & 0.11 & 0.04 & $\begin{array}{c}\text { Voriconazole } \\
\left(\mathrm{NA}^{\#}\right) \text { then } \\
\text { isavuconazole } \\
\left(\mathrm{NA}^{\#}\right)\end{array}$ & Death \\
\hline $\begin{array}{c}\text { Patient } \\
03\end{array}$ & $\mathrm{M}$ & 66 & $\begin{array}{c}\text { Hematological } \\
\text { malignancy (acute } \\
\text { leukemia) }\end{array}$ & Yes & $\begin{array}{c}\text { Corticosteroids + } \\
\text { methotrexate }\end{array}$ & $\begin{array}{c}\text { Posaconazole } \\
(300 \mathrm{mg} / \mathrm{d}, 2 \\
\text { weeks })\end{array}$ & $\begin{array}{l}\text { Probable } \\
\text { (lung) }\end{array}$ & $\begin{array}{c}\text { Ground glass } \\
\text { opacities and } \\
\text { lung } \\
\text { consolidation }\end{array}$ & Nidulantes & A. sydowii & $>12$ & 2.36 & $\begin{array}{c}\text { Caspofungin } \\
+ \text { liposomal } \\
\text { amphotericin } \\
\text { B }(3 \mathrm{mg} / \mathrm{kg} / \mathrm{d}) \\
\text { then } \\
\text { voriconazole } \\
\text { IV }\end{array}$ & Alive \\
\hline $\begin{array}{c}\text { Patient } \\
04\end{array}$ & $\mathrm{~F}$ & 58 & $\begin{array}{c}\text { Auto-immune } \\
\text { disease } \\
\text { (antiphospholipids } \\
\text { syndrom) }\end{array}$ & No & $\begin{array}{c}\text { Corticosteroids ( } \\
\text { bolus) }\end{array}$ & No & $\begin{array}{c}\text { Probable } \\
\text { (lung) }\end{array}$ & $\begin{array}{c}\text { Alveolar } \\
\text { consolidations }\end{array}$ & Nidulantes & A. sublatus & 0.84 & 8.78 & $\begin{array}{l}\text { Voriconazole } \\
(400 \mathrm{mg} \mathrm{x} \\
2 / \mathrm{d})\end{array}$ & Alive \\
\hline
\end{tabular}

This article is protected by copyright. All rights reserved 


\begin{tabular}{|c|c|c|c|c|c|c|c|c|c|c|c|c|c|c|}
\hline $\begin{array}{c}\text { Patient } \\
05\end{array}$ & $\mathrm{M}$ & 67 & $\begin{array}{c}\text { Hematological } \\
\text { malignancy (acute } \\
\text { leukemia) }\end{array}$ & Yes & No & No & $\begin{array}{l}\text { Probable } \\
\text { (lung) }\end{array}$ & $\begin{array}{l}\text { Multiple lung } \\
\text { consolidations }\end{array}$ & Fumigati & $\begin{array}{c}A . \\
\text { udagawae }\end{array}$ & 2.92 & 0.29 & $\begin{array}{l}\text { Voriconazole } \\
(200 \mathrm{mg} \mathrm{x} \\
2 / \mathrm{d})\end{array}$ & Death \\
\hline $\begin{array}{c}\text { Patient } \\
06\end{array}$ & $\mathrm{M}$ & 52 & $\begin{array}{c}\text { Hematological } \\
\text { malignancy } \\
\text { (lymphoproliferative } \\
\text { disease) }\end{array}$ & Yes & Brentuximab & No & $\begin{array}{l}\text { Probable } \\
\text { (lung) }\end{array}$ & NA & Nidulantes & A. sublatus & 1 & 0.375 & $\begin{array}{c}\text { Liposomal } \\
\text { amphotericin } \\
\mathrm{B}(3 \mathrm{mg} / \mathrm{kg} / \mathrm{d}) \\
\text { then } \\
\text { voriconazole } \\
(200 \mathrm{mg} \mathrm{x} \\
2 / \mathrm{j})\end{array}$ & Death \\
\hline $\begin{array}{c}\text { Patient } \\
07\end{array}$ & $\mathrm{M}$ & 28 & $\begin{array}{c}\text { Solid organ } \\
\text { transplant (liver) }\end{array}$ & No & Calcineurin inhibitor & No & $\begin{array}{l}\text { Probable } \\
\text { (lung) }\end{array}$ & $\begin{array}{c}\text { Lung } \\
\text { consolidations } \\
\text { and bilateral } \\
\text { ground glass } \\
\text { opacities }\end{array}$ & Nidulantes & A. sublatus & 4.06 & 3.6 & $\begin{array}{l}\text { Voriconazole } \\
\qquad\left(\mathrm{NA}^{\#}\right)\end{array}$ & Death \\
\hline $\begin{array}{c}\text { Patient } \\
08\end{array}$ & $\mathrm{M}$ & 64 & $\begin{array}{c}\text { Solid organ } \\
\text { transplant (heart) }\end{array}$ & No & $\begin{array}{l}\text { Corticosteroids + } \\
\text { calcineurin inhibitor } \\
+ \text { mycophenolate }\end{array}$ & \begin{tabular}{|c|} 
Voriconazole \\
$(200 \mathrm{mg} \mathrm{x}$ \\
$2 / \mathrm{d}, 3$ \\
months $)$
\end{tabular} & $\begin{array}{l}\text { Probable } \\
\text { (lung) }\end{array}$ & $\begin{array}{c}\text { Inverted halo } \\
\text { opacity }\end{array}$ & Usti & $\begin{array}{c}\text { A. } \\
\text { calidoustus }\end{array}$ & 0.08 & 0.64 & $\begin{array}{l}\text { Voriconazole } \\
(200 \mathrm{mg} \mathrm{x} \\
2 / \mathrm{d})\end{array}$ & Alive \\
\hline $\begin{array}{c}\text { Patient } \\
09\end{array}$ & $\mathrm{~F}$ & 58 & $\begin{array}{c}\text { ICU ARDS + } \\
\text { ECMO (severe } \\
\text { influenza infection) }\end{array}$ & No & Corticosteroids & No & $\begin{array}{l}\text { Putative } \\
\text { (lung) }\end{array}$ & $\begin{array}{c}\text { Bilateral lung } \\
\text { opacities }\end{array}$ & Nidulantes & A. sublatus & $>8$ & $>8$ & $\begin{array}{c}\text { Amphotericin } \\
\text { B } \\
\text { deoxycholate } \\
\left(\mathrm{NA}^{\#}\right)\end{array}$ & Death \\
\hline $\begin{array}{c}\text { Patient } \\
10\end{array}$ & $\mathrm{M}$ & 54 & $\begin{array}{c}\text { ICU ARDS + } \\
\text { ECMO (severe } \\
\text { influenza infection) }\end{array}$ & No & $\begin{array}{l}\text { Corticosteroids (+ } \\
\text { bolus) }\end{array}$ & No & $\begin{array}{l}\text { Proven } \\
\text { (lung) }\end{array}$ & $\begin{array}{c}\text { Bilateral lung } \\
\text { consolidations } \\
\text { and maxillary } \\
\text { sinusitis }\end{array}$ & Nigri & $\begin{array}{c}\text { A. } \\
\text { tubingensis }\end{array}$ & $>8$ & 6.9 & $\begin{array}{l}\text { Voriconazole } \\
(200 \mathrm{mg} \mathrm{x} \\
2 / \mathrm{d})\end{array}$ & Death \\
\hline $\begin{array}{c}\text { Patient } \\
11\end{array}$ & M & 74 & $\begin{array}{c}\text { Hematological } \\
\text { malignancy } \\
\text { (myelodysplastic } \\
\text { syndrom) }\end{array}$ & Yes & Corticosteroids & No & $\begin{array}{l}\text { Probable } \\
\text { (lung) }\end{array}$ & $\begin{array}{l}\text { Lung nodules } \\
\text { and } \\
\text { consolidation }\end{array}$ & Nidulantes & A. sublatus & 0.46 & 0.088 & $\begin{array}{l}\text { Voriconazole } \\
(200 \mathrm{mg} \mathrm{x} \\
\text { 2/d) then } \\
\text { liposomal }\end{array}$ & Death \\
\hline
\end{tabular}

This article is protected by copyright. All rights reserved 


\begin{tabular}{|c|c|c|c|c|c|c|c|c|c|c|c|c|c|c|}
\hline & & & & & & & & & & & & & $\begin{array}{l}\text { amphotericin } \\
\text { B }(3 \mathrm{mg} / \mathrm{kg} / \mathrm{d})\end{array}$ & \\
\hline $\begin{array}{c}\text { Patient } \\
12\end{array}$ & M & 70 & ICU ARDS & No & No & $\begin{array}{c}\text { Caspofungin } \\
(50 \mathrm{mg} / \mathrm{d}, 2 \\
\text { months })\end{array}$ & $\begin{array}{l}\text { Proven } \\
\text { (lung) }\end{array}$ & $\begin{array}{c}\text { Alveolar } \\
\text { consolidations } \\
\text { and ground } \\
\text { glass } \\
\text { opacities }\end{array}$ & Fumigati & A. lentulus & $\mathrm{NA}^{\#}$ & 3.2 & $\begin{array}{c}\text { Liposomal } \\
\text { amphotericin } \\
\text { B (3mg/kg/d) } \\
+ \\
\text { caspofungin }\end{array}$ & Death \\
\hline $\begin{array}{c}\text { Patient } \\
13\end{array}$ & M & 67 & $\begin{array}{c}\text { Solid organ } \\
\text { transplant (lung) }\end{array}$ & No & $\begin{array}{l}\text { Corticosteroids }(+ \\
\text { bolus) }+ \text { calcineurin } \\
\text { inhibitor }\end{array}$ & No & $\begin{array}{l}\text { Probable } \\
\text { (lung) }\end{array}$ & $\begin{array}{c}\text { Lung } \\
\text { consolidations }\end{array}$ & Nigri & $\begin{array}{c}\text { A. } \\
\text { tubingensis }\end{array}$ & $\mathrm{NA}^{\#}$ & $\mathrm{NA}^{\#}$ & $\begin{array}{c}\text { Voriconazole } \\
(250 \mathrm{mg} \mathrm{x} \\
2 / \mathrm{d})+ \\
\text { aerosolized } \\
\text { amphotericin } \\
\text { B }\end{array}$ & Alive \\
\hline $\begin{array}{c}\text { Patient } \\
14\end{array}$ & M & 58 & $\begin{array}{c}\text { Solid organ } \\
\text { transplant (heart) }\end{array}$ & No & $\begin{array}{l}\text { Corticosteroids }+ \\
\text { calcineurin inhibitor }\end{array}$ & \begin{tabular}{|c|} 
Voriconazole \\
$(200 \mathrm{mg} \mathrm{x}$ \\
$2 / \mathrm{d}, 3$ \\
months $)$
\end{tabular} & $\begin{array}{l}\text { Proven } \\
\text { (bone) }\end{array}$ & $\begin{array}{l}\text { Vertebral } \\
\text { osteolysis }\end{array}$ & Usti & $\begin{array}{c}\text { A. } \\
\text { calidoustus }\end{array}$ & $\mathrm{NA}^{\#}$ & 0.83 & $\begin{array}{l}\text { Voriconazole } \\
\qquad\left(\mathrm{NA}^{\#}\right)\end{array}$ & Death \\
\hline $\begin{array}{c}\text { Patient } \\
15\end{array}$ & M & 65 & $\begin{array}{c}\text { Hematological } \\
\text { malignancy (acute } \\
\text { leukemia) }\end{array}$ & Yes & $\begin{array}{c}\text { Induction } \\
\text { chemotherapy }\end{array}$ & $\begin{array}{c}\text { Posaconazole } \\
(300 \mathrm{mg} / \mathrm{d}, 3 \\
\text { weeks })\end{array}$ & $\begin{array}{c}\text { Probable } \\
\text { (lung) }\end{array}$ & $\begin{array}{c}\text { Bilateral lung } \\
\text { nodules }\end{array}$ & Flavi & $\begin{array}{c}\text { A. } \\
\text { alliaceus }\end{array}$ & $\mathrm{NA}^{\#}$ & 0.56 & $\begin{array}{c}\text { Voriconazole } \\
(200 \mathrm{mg} \mathrm{x} \\
2 / \mathrm{d})\end{array}$ & Alive \\
\hline
\end{tabular}

This article is protected by copyright. All rights reserved 
Table 2: antifungal susceptibility testing for cryptic species involved in invasive aspergillosis

\begin{tabular}{|c|c|c|c|c|c|c|c|}
\hline \multirow{2}{*}{ Section } & \multirow{2}{*}{\multicolumn{2}{|c|}{ Species }} & \multicolumn{5}{|c|}{$\begin{array}{c}\text { MIC } \\
\text { MIC50 / MIC90 (Range); mg/L }\end{array}$} \\
\hline & & & Itraconazole & Voriconazole & Posaconazole & Isavuconazole & $\begin{array}{c}\text { Amphotericin } \\
\text { B }\end{array}$ \\
\hline \multirow{2}{*}{ Flavi } & \multirow{2}{*}{ A. alliaceus } & $\begin{array}{l}\text { Invasive isolate } \\
\qquad(n=1)\end{array}$ & 0.125 & 0.25 & 0.125 & 0.25 & $>16$ \\
\hline & & All isolates $(n=12)$ & $\begin{array}{l}0.125 / 0.125 \\
(0.06-0.125)\end{array}$ & $\begin{array}{c}0.25 / 0.5 \\
(0.25-0.5)\end{array}$ & $\begin{array}{l}0.06 / 0.125 \\
(0.015-0.25)\end{array}$ & $\begin{array}{c}0.5 / 1 \\
(0.25-1)\end{array}$ & $\begin{array}{c}>16 />16 \\
(4->16)\end{array}$ \\
\hline \multirow{6}{*}{ Fumigati } & \multirow[t]{2}{*}{ A. fischeri } & $\begin{array}{l}\text { Invasive isolate } \\
\qquad(n=1)\end{array}$ & $>8$ & 2 & 0.5 & 2 & 1 \\
\hline & & All isolates $(n=3)$ & $>8$ & 2 & $0.25-0.5$ & 2 & $1-2$ \\
\hline & \multirow{2}{*}{$\begin{array}{c}\text { A. } \\
\text { udagawae }\end{array}$} & $\begin{array}{l}\text { Invasive isolate } \\
\qquad(n=1)\end{array}$ & 2 & 2 & 0.25 & 2 & 4 \\
\hline & & All isolates $(n=4)$ & $2->8$ & $2-4$ & $0.25-0.5$ & $2-4$ & $1-8$ \\
\hline & \multirow{2}{*}{ A. lentulus } & $\begin{array}{l}\text { Invasive isolate } \\
\qquad(n=1)\end{array}$ & 0.5 & 4 & 0.25 & 2 & 1 \\
\hline & & All isolates $(n=9)$ & $0.5->8$ & $2-8$ & $0.25-0.5$ & $0.5-4$ & $1-8$ \\
\hline \multirow{4}{*}{ Nidulantes } & \multirow{2}{*}{ A. sydowii } & $\begin{array}{l}\text { Invasive isolate } \\
\qquad(n=1)\end{array}$ & $>8$ & 1 & 1 & 1 & $>16$ \\
\hline & & All isolates $(n=34)$ & $\begin{array}{c}>8 />8 \\
(0.25->8)\end{array}$ & $\begin{array}{c}2 / 2 \\
(0.25-4)\end{array}$ & $\begin{array}{c}0.5 / 1 \\
(0.25-1)\end{array}$ & $\begin{array}{c}1 / 2 \\
(0.25-2)\end{array}$ & $\begin{array}{l}4 />16 \\
(1->16)\end{array}$ \\
\hline & \multirow{2}{*}{ A. latus } & $\begin{array}{l}\text { Invasive isolates } \\
\qquad(n=5)\end{array}$ & $0.25-0.5$ & $0.25-0.5$ & $0.125-0.5$ & $0.125-0.25$ & 0.5 \\
\hline & & All isolates $(n=30)$ & $\begin{array}{l}0.5 / 0.5 \\
(0.25-1)\end{array}$ & $\begin{array}{l}0.5 / 0.5 \\
(0.25-1)\end{array}$ & $\begin{array}{c}0.25 / 0.5 \\
(0.125-0.5)\end{array}$ & $\begin{array}{c}0.25 / 0.5 \\
(0.125-0.5)\end{array}$ & $\begin{array}{l}0.5 / 0.5 \\
(0.25-1)\end{array}$ \\
\hline \multirow{2}{*}{ Nigri } & \multirow{2}{*}{$\begin{array}{c}\text { A. } \\
\text { tubingensis }\end{array}$} & $\begin{array}{l}\text { Invasive isolates } \\
\qquad(n=2)\end{array}$ & $>8$ & 2 & 0,25 & $2-4$ & 0,5 \\
\hline & & All isolates $(n=10)$ & $\begin{array}{l}>8 />8 \\
(0.5->8)\end{array}$ & $\begin{array}{l}2 / 2 \\
(1-2)\end{array}$ & $\begin{array}{l}0.25 / 0.25 \\
(0.125-0.5)\end{array}$ & $\begin{array}{l}4 / 4 \\
(1-4)\end{array}$ & $\begin{array}{c}0.5 / 0.5 \\
(0.125-0.5)\end{array}$ \\
\hline \multirow{2}{*}{ Usti } & \multirow{2}{*}{$\begin{array}{c}\text { A. } \\
\text { calidoustus }\end{array}$} & $\begin{array}{l}\text { Invasive isolates } \\
\qquad(\mathrm{n}=3)\end{array}$ & $>8$ & $8-16$ & $>8$ & 4 & 1 \\
\hline & & All isolates $(n=18)$ & $\begin{array}{c}>8 />8 \\
(>8)\end{array}$ & $\begin{array}{l}8 / 16 \\
(4-16)\end{array}$ & $\begin{array}{c}>8 />8 \\
(>8)\end{array}$ & $\begin{array}{c}4 / 4 \\
(2->8)\end{array}$ & $\begin{array}{c}1 / 2 \\
(0.25-2)\end{array}$ \\
\hline
\end{tabular}

MIC: Minimal Inhibitory Concentration. MIC50 and MIC90 are shown when more than 10 isolates for the same species were assessed during the study period.

This article is protected by copyright. All rights reserved 
Table 3: characteristics comparison between Aspergillus cryptic species and $A$. fumigatus sensu stricto invasive aspergillosis

\begin{tabular}{|c|c|c|c|}
\hline & $\begin{array}{c}\text { Cryptic species } \\
(n=15)\end{array}$ & A. fumigatus $(\mathrm{n}=51)$ & p value \\
\hline \multicolumn{4}{|l|}{ Demographic characteristics } \\
\hline Median age (years) & $58(28-74)$ & $57(23-84)$ & 0.52 \\
\hline Sex ratio $(M / F)$ & $11 / 4$ & $38 / 13$ & 1 \\
\hline \multicolumn{4}{|l|}{ Underlying diseases } \\
\hline Hematological malignancy & $5(33 \%)$ & $14(27.5 \%)$ & 0.75 \\
\hline Hematopoietic stem cell transplant & $0(0 \%)$ & $4(7.8 \%)$ & 0.57 \\
\hline Solid organ transplantation & $6(40 \%)$ & $20(39.2 \%)$ & 1 \\
\hline Acute respiratory distress syndrom & $3(20 \%)$ & $7(13.7 \%)$ & 0.68 \\
\hline Other & $1(6.7 \%)$ & $6(11.8 \%)$ & 1 \\
\hline \multicolumn{4}{|l|}{ Underlying Immunosuppressive condition } \\
\hline Neutropenia (absolute neutrophils count $<500 / \mu \mathrm{L}$ ) & $5(33 \%)$ & $12(23.5 \%)$ & 0.5 \\
\hline Immunosuppressive drug & $13(86.7 \%)$ & $39(76.5 \%)$ & 0.49 \\
\hline Including corticosteroids & $10(66.7 \%)$ & $29(58.9 \%)$ & 0.56 \\
\hline Antifungal drug pre-exposure & $5(33 \%)$ & $13(25.5 \%)$ & 0.53 \\
\hline Including azole drugs & $4(26.7 \%)$ & $2(3.9 \%)$ & 0.02 \\
\hline Targeted antifungal therapy & $15(100 \%)$ & $49(96.1 \%)$ & 1 \\
\hline Including azole drugs & $13(86.7 \%)$ & $43(84.3 \%)$ & 1 \\
\hline Combination therapy & $6(40 \%)$ & $13(25.5 \%)$ & 0.33 \\
\hline \multicolumn{4}{|l|}{ Invasive aspergillosis classification } \\
\hline Proven & 2 & 6 & 1 \\
\hline Probable & 11 & 50 & 0.73 \\
\hline Putative & 2 & 5 & 0.65 \\
\hline \multicolumn{4}{|l|}{ Galactomannan index positivity } \\
\hline Serum $(\geq 0.5)$ & $10 / 14(71.4 \%)$ & $26 / 48(54.2 \%)$ & 0.36 \\
\hline Broncho-alveolar lavage $(\geq 1)$ & $6 / 10(60 \%)$ & $26 / 45(57.8 \%)$ & 1 \\
\hline Three-month all cause mortality & $9(60 \%)$ & $31(61 \%)$ & 1 \\
\hline
\end{tabular}

*Student t-test, Chi square test or Fischer exact test were used when suitable 